WILDFLOWERS OF CALIFORNIA

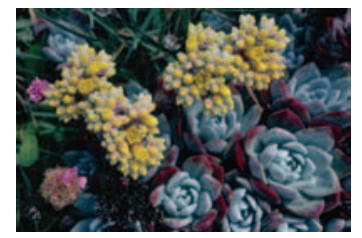

A MONTH-BY-MONTH GUIDE 
The publisher gratefully acknowledges the generous support of the General Endowment Fund of the University of California Press Foundation. 


\section{WILDFLOWERS OF}

\section{CALIFORNIA}

A Month-by-Month Guide

\section{Laird R. Blackwell .. :}

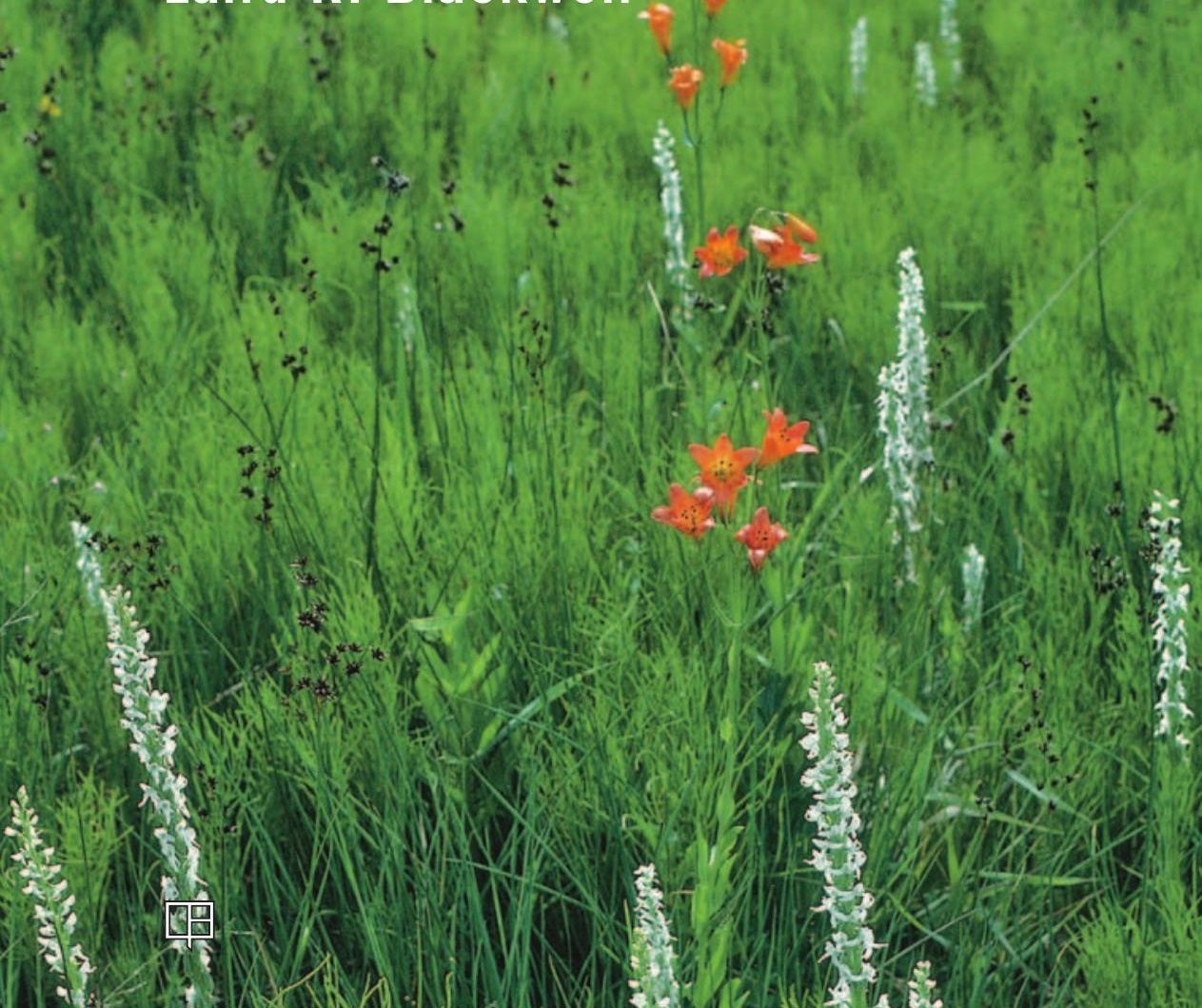

UN $y$ ERSIY OF CALIFOF A RRESS Berkeley I Tos Angeles , tondon

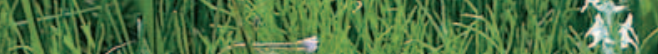


University of California Press, one of the most distinguished university presses in the United States, enriches lives around the world by advancing scholarship in the humanities, social sciences, and natural sciences. Its activities are supported by the UC Press Foundation and by philanthropic contributions from individuals and institutions. For more information, visit www.ucpress.edu.

University of California Press

Berkeley and Los Angeles, California

University of California Press, Ltd.

London, England

(C) 2012 by The Regents of the University of California

Library of Congress Cataloging-in-Publication Data

Blackwell, Laird R. (Laird Richard), 1945-

Wildflowers of California : a month-by-month guide / Laird R. Blackwell.

p. $\mathrm{cm}$.

Includes bibliographical references and indexes.

ISBN 978-0-520-27205-7 (cloth : alk. paper)-ISBN 978-0-520-27206-4 (cloth : alk. paper)

1. Wild flower-California-Identification. 2. Wild flowers-California-Pictorial works. I. Title.

QK149.B586 2012

$582.1309794-\mathrm{dc} 23$

2011024363

Manufactured in Singapore

$\begin{array}{llllllll}19 & 18 & 17 & 16 & 15 & 14 & 13 & 12\end{array}$

$\begin{array}{llllllllll}10 & 9 & 8 & 7 & 6 & 5 & 4 & 3 & 2 & 1\end{array}$

The paper used in this publication meets the minimum requirements of ANSI/NISO Z39.481992 (R 1997) (Permanence of Paper). $\infty$

Cover photograph: Poppies and goldfields along Hite's Cove Trail on the south fork of the Merced River.

Note: All photographs were taken by the author. 
For my beautiful, wise, loving wife, Melinda, and for our wonderful granddaughters Isla and Ava, who are being raised with laughter and adventure and nature's wonder. 


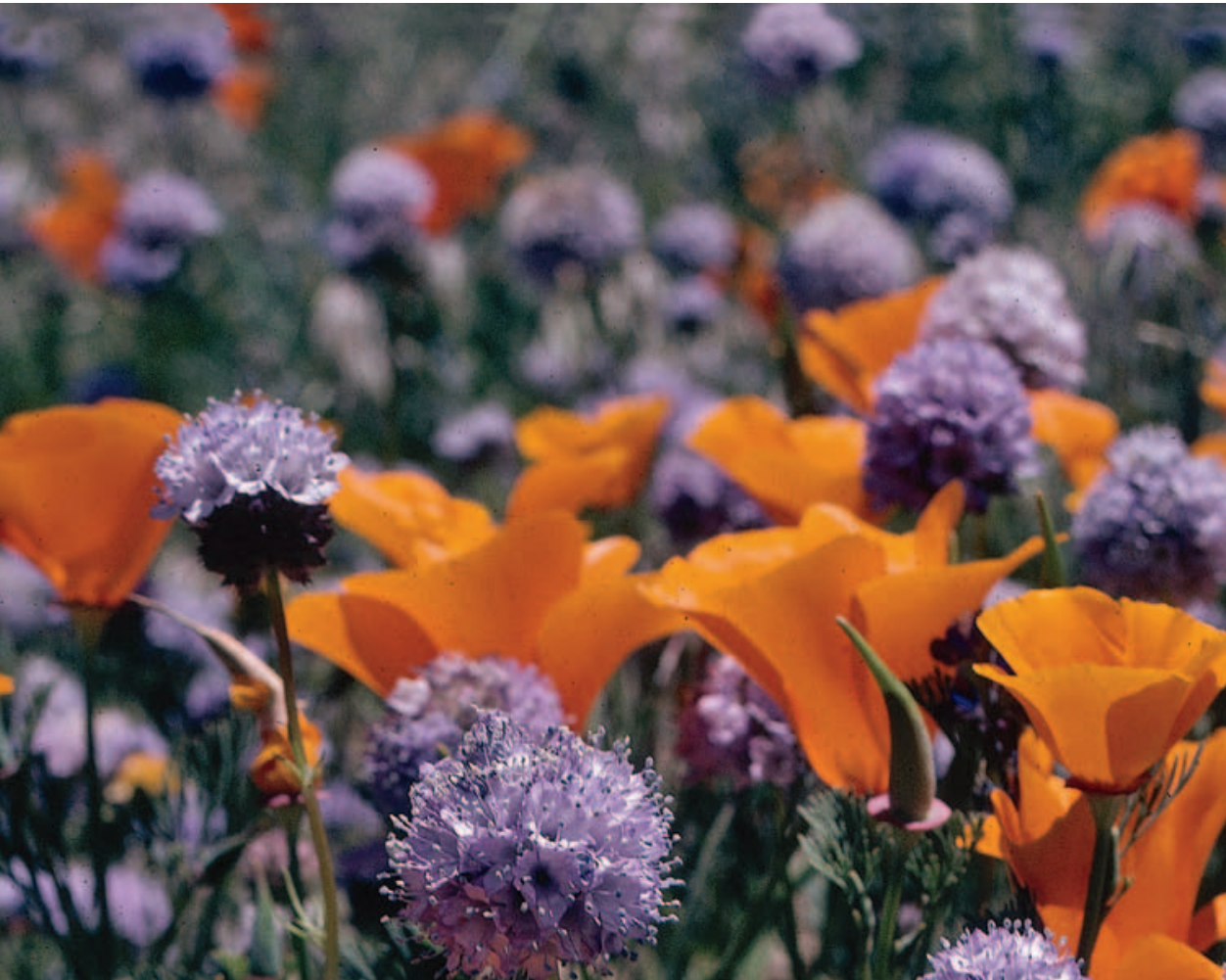

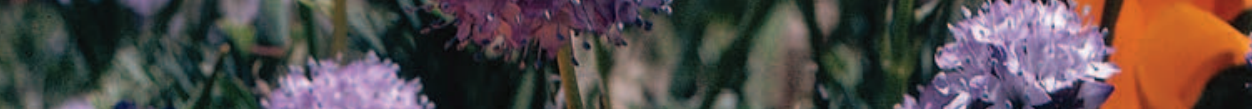

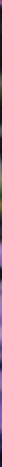

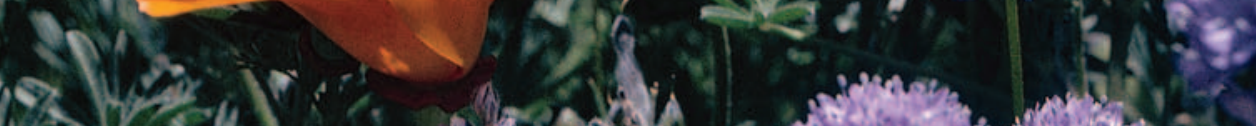

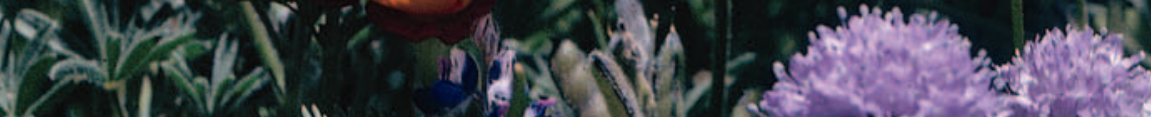

